\title{
Oscillations in oxygen tension and insulin release of individual pancreatic ob/ob mouse islets
}

\author{
H. Ortsäter ${ }^{1}$, P.Liss ${ }^{2}$, P. E. Lund ${ }^{2}$, K. E. O. Åkerman ${ }^{2}$, P. Bergsten ${ }^{1}$ \\ ${ }^{1}$ Department of Medical Cell Biology, Uppsala University, Uppsala, Sweden \\ ${ }^{2}$ Department of Physiology, Uppsala University, Uppsala, Sweden
}

\section{Abstract}

Aims/hypothesis. The role of beta-cell metabolism for generation of oscillatory insulin release was investigated by simultaneous measurements of oxygen tension $\left(\mathrm{pO}_{2}\right)$ and insulin release from individual islets of Langerhans.

Methods. Individual islets isolated from the $o b / o b$ mice were perifused. Insulin in the perifusate was measured with a sensitive ELISA and $\mathrm{pO}_{2}$ with a modified Clark-type electrode inserted into the islets. Results. In the presence of $3 \mathrm{mmol} / \mathrm{l} \mathrm{D}$-glucose, $\mathrm{pO}_{2}$ was $102 \pm 9 \mathrm{mmHg}$ and oscillatory $(0.26 \pm 0.04$ oscillations/min). Corresponding insulin measurements showed oscillatory release with similar periodicity $(0.25 \pm 0.02$ oscillations $/ \mathrm{min})$. When the $\mathrm{D}$-glucose concentration was increased to $11 \mathrm{mmol} / 1, \mathrm{pO}_{2}$ decreased by $30 \%$ to $72 \pm 10 \mathrm{mmHg}$ with maintained frequency of the oscillations. Corresponding insulin secretory rate rose from $5 \pm 2$ to $131 \pm 16$ $\mathrm{pmol} \cdot \mathrm{g}^{-1} \cdot \mathrm{s}^{-1}$ leaving the frequency of the insulin pulses unaffected. The magnitude of glucose-induced change in $\mathrm{pO}_{2}$ varied between islets but was positively correlated to the amount of insulin released $\left(r^{2}=0.85\right)$. When $1 \mathrm{mmol} / \mathrm{l}$ tolbutamide was added to the perifusion medium containing $11 \mathrm{mmol} / \mathrm{l}$ glucose no change in average oscillatory $\mathrm{pO}_{2}$ was observed despite a doubling in the secretory rate. When $8 \mathrm{mmol} / \mathrm{l} 3$-oxymethyl glucose was added to perifusion medium containing $3 \mathrm{mmol} / \mathrm{l}$ D-glucose, neither $\mathrm{pO}_{2}$ nor insulin release of the islets were changed. Temporal analysis of oscillations in $\mathrm{pO}_{2}$ and insulin release revealed that maximum respiration correlated to maximum or close to maximum insulin release.

Conclusion/interpretation. The temporal relation between oscillations in $\mathrm{pO}_{2}$ and insulin release supports a role for metabolic oscillations in the generation of pulsatile insulin release. [Diabetologia (2000) 43: 1313-1318]

Keywords Oscillation, metabolism, oxygen tension, insulin release, islet, glucose, tolbutamide, heterogeneity, Clark electrode, ELISA.
Insulin is released in $4-5 \mathrm{~min}$ pulses from isolated islets [1]. The rhythmic release of the hormone is decisive for the appearance of plasma insulin oscillations $[2,3]$, which are important for the blood glucose lowering effect of the hormone $[4,5,6]$. Despite the importance of pulsatile insulin release, the origin of the oscillations is still not clear. Regular variations of dif-

Received: 9 March 2000 and in revised form: 19 May 2000

Corresponding author: P. Bergsten, Department of Medical Cell Biology, Box 571, Uppsala University, 75123 Uppsala, Sweden ferent metabolic variables such as oxygen consumption, ATP:ADP ratio, lactate release and pyridine nucleotides have been measured both in intact pancreatic beta cells and in permeabilized clonal beta cells incubated in an oscillating glycolytic muscle extract $[7,8,9,10,11,12,13]$. These metabolic oscillations show similar frequencies as the insulin oscillations of isolated islets $[1,9,14]$, which supports the concept of an oscillatory metabolism underlying pulsatile insulin release [15]. Oscillations in the cytoplasmic $\mathrm{Ca}^{2+}$ concentration $\left(\left[\mathrm{Ca}^{2+}\right]_{\mathrm{i}}\right)$ have also been proposed to initiate the secretory pulses. This idea was strongly supported by results from simultaneous measurements 
of $\left[\mathrm{Ca}^{2+}\right]_{\mathrm{i}}$ and insulin release from individual islets in which oscillations in the two variables coincided [14, 16]. When it was discovered that pulsatile insulin secretion was not always accompanied by oscillatory $\left[\mathrm{Ca}^{2+}\right]_{\mathrm{i}}[17,18,19]$, the role of $\left[\mathrm{Ca}^{2+}\right]_{\mathrm{i}}$ as a generator of the secretory pulses became less clear. The idea of a metabolic oscillator was once again proposed although it was not known whether metabolic oscillations existed when pulsatile insulin release was not accompanied by oscillatory $\left[\mathrm{Ca}^{2+}\right]_{\mathrm{i}}$. To further investigate the role of metabolic oscillations in the generation of pulsatile insulin release we have used sensitive techniques $[1,20]$, which enabled us to do dynamic measurements of insulin release and $\mathrm{pO}_{2}$ from single islets of Langerhans also under conditions associated with stationary $\left[\mathrm{Ca}^{2+}\right]_{i}$.

\section{Materials and methods}

Chemicals. Reagents of analytical grade and deionized water were used. Collagenase (lot no. 83963721-35), HEPES and bovine serum albumin (fraction $\mathrm{V}$ ) were obtained from Boehringer Mannheim (Mannheim, Germany). The D-glucose, 3oxymethyl glucose, tetramethylbenzidine and insulin-peroxidase came from Sigma (St. Louis, Mo., USA). The rat insulin standard was from Novo Nordisk (Bagsvaerd, Denmark). The IgG-certified microtitre plates were purchased from Nunc (Roskilde, Denmark). Tolbutamide was from Hoechst (Frankfurt, Germany). The mouse insulin antibodies were generated in our laboratory from guinea-pigs.

Preparation and perifusion of islets. Pancreatic islets were isolated by collagenase from $15 \mathrm{ob} / \mathrm{ob}$ mice [21]. Keeping and handling of the mice and experimental procedures were approved by the local animal ethics committee in accordance with NIH publication No. 85-23. Single freshly isolated islets $(n=24)$ were mounted on a cover slip coated with poly-L-lysine, which was used as the bottom of a perifusion chamber maintained at $37^{\circ} \mathrm{C}$ by a thermostat [14]. The islets were perifused at a rate of 150-200 $\mu \mathrm{l}$ per min with a medium supplemented with $1 \mathrm{mg} / \mathrm{ml}$ albumin and containing (in $\mathrm{mmol} / \mathrm{l}$ ): $\mathrm{NaCl} 125, \mathrm{KCl} 5.9, \mathrm{MgCl}_{2} 1.2, \mathrm{CaCl}_{2}$ 1.28, HEPES 25 and $\mathrm{D}-$ glucose 3 , titrated to $\mathrm{pH} 7.4$ with $\mathrm{NaOH}$. After 60 min, oxygen tension was measured in the presence of $3 \mathrm{mmol} / \mathrm{l} \mathrm{D}$-glucose and the perifusate was collected in 20-s fractions for measurement of insulin. The time required for the perifusate to be pumped from the islet to the collection point was $120 \mathrm{~s}$. This lag period has been taken into account in all calculations. In experiments where either the D-glucose concentration was increased to $11 \mathrm{mmol} / \mathrm{l}$ or $8 \mathrm{mmol} / \mathrm{l} 3$-oxymethyl glucose was added to the perifusion medium, measurements of oxygen tension and insulin release were interrupted for $10 \mathrm{~min}$ after increasing the glucose concentration. After subsequent measurements for approximately $20 \mathrm{~min}, 1 \mathrm{mmol} / \mathrm{l}$ tolbutamide was added to the perifusion medium without interrupting the measurements. In experiments where $1 \mathrm{mmol} / \mathrm{l}$ tolbutamide was added to perifusion medium containing $3 \mathrm{mmol} / \mathrm{l} \mathrm{D}$-glucose there was no interruption in sampling.

Measurements of oxygen tension. Oxygen tension in the isolated islets was measured by a modified Clark microelectrode [20]. The tip of the microelectrode was positioned into the islets with the aid of a micromanipulator [22]. A stereomicro- scope (Nikon, Tokyo, Japan) was used to control the penetration depth of the electrode, which was 25-50 $\mu \mathrm{m}$. In two experiments the tip broke and the experiments were interrupted and not analysed. In the absence of islets no changes in oxygen tension were observed when perifusing the electrode with perifusion medium, which had regular changes in the glucose or insulin concentration from 3 to $11 \mathrm{mmol} / \mathrm{l}$ and 0 to $1 \mathrm{pmol} / \mathrm{l}$, respectively. The electrodes were polarised at $-0.8 \mathrm{~V}$, which gave a linear response between the oxygen tension and the electrode current. The electrical current was measured by picoamperemeters (University of Aarhus, Aarhus, Denmark). The sampling rate of the A/D converter was 4 data points per s. Averages of data points corresponding to $20 \mathrm{~s}$ of recordings were calculated and used for the further data presentation. The electrodes were calibrated in water saturated with $\mathrm{Na}_{2} \mathrm{~S}_{2} \mathrm{O}_{5}$ or air at $37^{\circ} \mathrm{C}$ before and after the experiments. The drift of the microelectrodes was less than $0.5 \%$ per $h$.

Measurements of insulin release. Insulin in the perifusate was assayed by a competitive ELISA with the insulin antibody immobilized directly onto the solid phase [1]. The assay showed linearity in a semilogarithmic diagram over the range of $0.1-$ $100 \mathrm{fmol}$ and had inter-assay and intra-assay variations of less than $10 \%$ in the specified range [1]. In one experiment the insulin assay standard curve was non-linear in the specified range and the experiment was excluded. The rate of insulin release was normalised to dry weight after freeze-drying and weighing the islets on a quartz fibre balance.

Data analysis. Frequency determination of oscillations in oxygen tension and insulin release was done by Fourier transformation on both original and autocorrelated data from 21 experiments using the Igor software (Wave Metrics, Lake Oswego, Ore., USA). In general, the relevant spectrum peak was clearly and uniquely identifiable. In all cases the corresponding area was more than three times higher than the adjacent parts of the spectrum, neglecting the extreme low frequency components derived from the drift. A sinus function was then fitted to the data. Phase shift between oxygen and insulin pulses was investigated by comparing at what time points the two variables had their peak values. The peak values were chosen in accordance with the fitted sinus function. To further investigate the temporal relation between oscillations in $\mathrm{pO}_{2}$ and insulin release the data series of the two variables were analysed by cross-correlation. The time difference between the two oscillatory patterns was expressed in periods.

Statistical analysis. Results are presented as means \pm SEM. Differences in average oxygen tension and secretory rates were evaluated with ANOVA for repeated measurements. Linear regression analysis was used to evaluate the correlation between oxygen tension and insulin release. Paired Student's $t$ test was used to evaluate the temporal differences between measurements of oxygen tension and insulin release.

\section{Results}

Oxygen tension and insulin release were measured simultaneously from individual islets of Langerhans. In the presence of $3 \mathrm{mmol} / \mathrm{l}$ D-glucose mean $\mathrm{pO}_{2}$ was $102 \pm 9 \mathrm{mmHg}$ and insulin release was $5 \pm 2$ pmol $\mathrm{g}^{-1} \cdot \mathrm{s}^{-1}$ (Fig. 1, Table 1). Both oxygen tension and insulin release were oscillatory with frequencies of $0.26 \pm 0.04$ and $0.25 \pm 0.02$ oscillations $/ \mathrm{min}$, respec- 

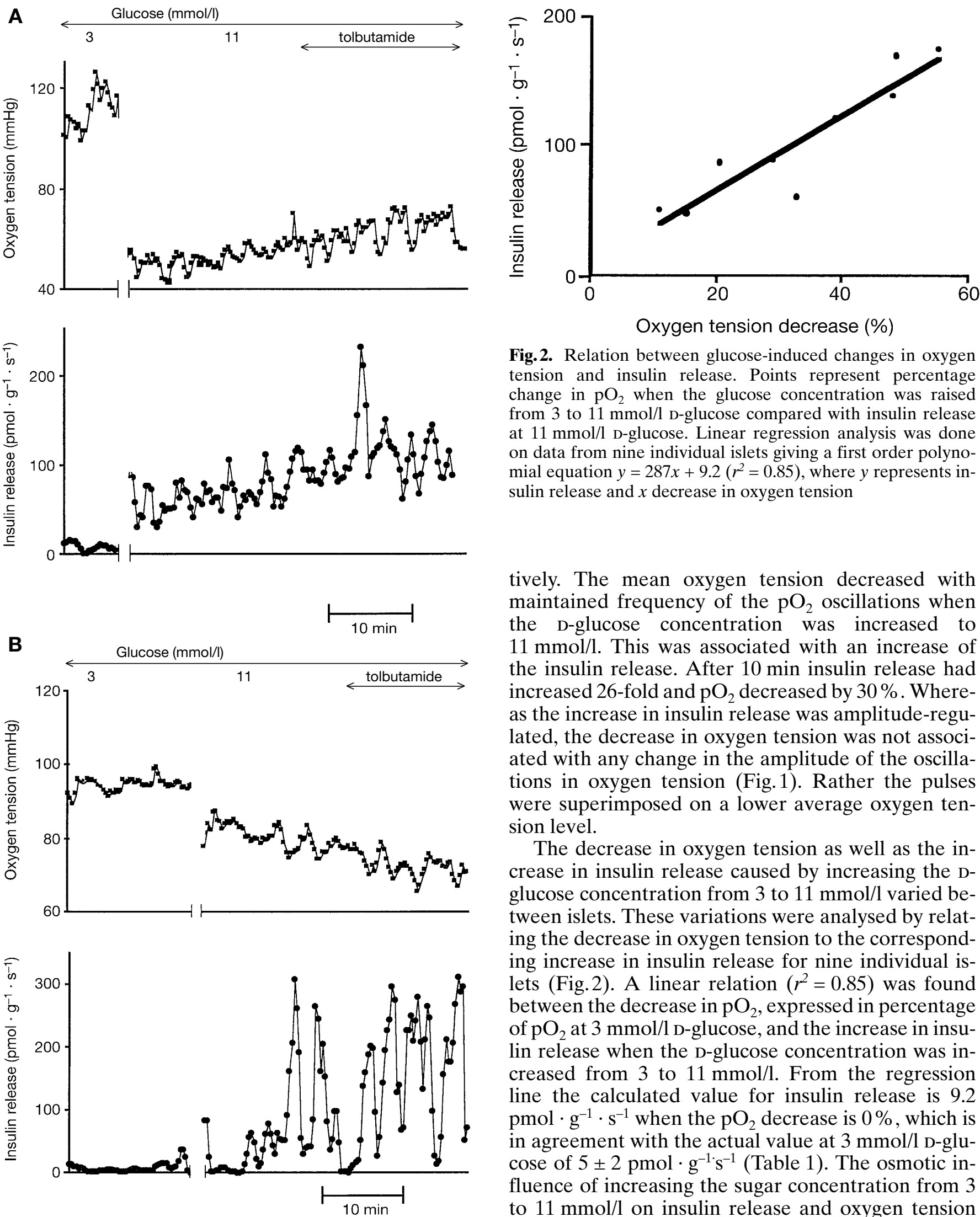

Fig.1A, B. Simultaneous measurements of $\mathrm{pO}_{2}$ (top panels) and insulin release (bottom panels) in individual islets perifused in the presence of $3,11 \mathrm{mmol} / \mathrm{l} \mathrm{D}$-glucose and $1 \mathrm{mmol} / \mathrm{l}$ tolbutamide. Two representative experiments out of six

Fig. 2. Relation between glucose-induced changes in oxygen tension and insulin release. Points represent percentage change in $\mathrm{pO}_{2}$ when the glucose concentration was raised from 3 to $11 \mathrm{mmol} / \mathrm{l} \mathrm{D}$-glucose compared with insulin release at $11 \mathrm{mmol} / \mathrm{l} \mathrm{D}$-glucose. Linear regression analysis was done on data from nine individual islets giving a first order polynomial equation $y=287 x+9.2\left(r^{2}=0.85\right)$, where $y$ represents insulin release and $x$ decrease in oxygen tension

tively. The mean oxygen tension decreased with maintained frequency of the $\mathrm{pO}_{2}$ oscillations when the $\mathrm{D}$-glucose concentration was increased to $11 \mathrm{mmol} / \mathrm{l}$. This was associated with an increase of the insulin release. After $10 \mathrm{~min}$ insulin release had increased 26 -fold and $\mathrm{pO}_{2}$ decreased by $30 \%$. Whereas the increase in insulin release was amplitude-regulated, the decrease in oxygen tension was not associated with any change in the amplitude of the oscillations in oxygen tension (Fig.1). Rather the pulses were superimposed on a lower average oxygen tension level.

The decrease in oxygen tension as well as the increase in insulin release caused by increasing the Dglucose concentration from 3 to $11 \mathrm{mmol} / \mathrm{l}$ varied between islets. These variations were analysed by relating the decrease in oxygen tension to the corresponding increase in insulin release for nine individual islets (Fig. 2). A linear relation $\left(r^{2}=0.85\right)$ was found between the decrease in $\mathrm{pO}_{2}$, expressed in percentage of $\mathrm{pO}_{2}$ at $3 \mathrm{mmol} / \mathrm{l} \mathrm{D}$-glucose, and the increase in insulin release when the $\mathrm{D}$-glucose concentration was increased from 3 to $11 \mathrm{mmol} / \mathrm{l}$. From the regression line the calculated value for insulin release is 9.2 $\mathrm{pmol} \cdot \mathrm{g}^{-1} \cdot \mathrm{s}^{-1}$ when the $\mathrm{pO}_{2}$ decrease is $0 \%$, which is in agreement with the actual value at $3 \mathrm{mmol} / \mathrm{l} \mathrm{D}$-glucose of $5 \pm 2 \mathrm{pmol} \cdot \mathrm{g}^{-1} \mathrm{~s}^{-1}$ (Table 1 ). The osmotic influence of increasing the sugar concentration from 3 to $11 \mathrm{mmol} / \mathrm{l}$ on insulin release and oxygen tension measurements was evaluated by adding $8 \mathrm{mmol} / \mathrm{l}$ 3-oxymethyl glucose to the perifusion containing $3 \mathrm{mmol} / \mathrm{l} \mathrm{D}$-glucose. No change in either oxygen tension or insulin release of the islets was observed after 
Table 1. Oxygen tension and insulin release measured in isolated mouse islets in the presence of different concentrations of D-glucose and tolbutamide

\begin{tabular}{|c|c|c|c|c|c|c|}
\hline \multirow{2}{*}{$\begin{array}{l}\text { D-Glucose } \\
(\mathrm{mmol} / \mathrm{l})\end{array}$} & \multirow{2}{*}{$\begin{array}{l}\text { Tolbutamide } \\
(\mathrm{mmol} / \mathrm{l})\end{array}$} & \multicolumn{2}{|c|}{ Oxygen tension } & \multicolumn{2}{|l|}{ Insulin release } & \multirow[t]{2}{*}{$n^{c}$} \\
\hline & & $\begin{array}{l}\text { Mean } \\
(\mathrm{mmHg})\end{array}$ & $\begin{array}{l}\text { Frequency } \\
\text { (osc/min) }\end{array}$ & $\begin{array}{l}\text { Mean } \\
\left(\mathrm{pmol} \cdot \mathrm{g}^{-1} \cdot \mathrm{s}^{-1}\right)\end{array}$ & $\begin{array}{l}\text { Frequency } \\
\text { (osc/min) }\end{array}$ & \\
\hline 3 & 1 & $99 \pm 6$ & $0.26+0.01$ & $30 \pm 9^{\mathrm{a}}$ & $0.29 \pm 0.01$ & 6 \\
\hline 11 & & $72 \pm 10^{\mathrm{b}}$ & $0.22 \pm 0.04$ & $131 \pm 16^{b}$ & $0.26 \pm 0.03$ & 6 \\
\hline 11 & 1 & $75 \pm 11$ & $0.23 \pm 0.02$ & $268 \pm 42^{\mathrm{a}}$ & $0.25 \pm 0.02$ & 6 \\
\hline
\end{tabular}

Simultaneous measurements of $\mathrm{pO}_{2}$ and insulin release were done in individual islets perifused in the presence of 3 and $11 \mathrm{mmol} / \mathrm{l} \mathrm{D}$-glucose in the presence or absence of $1 \mathrm{mmol} / \mathrm{l} \mathrm{tol}$ butamide.
${ }^{\text {a }} P<0.05$ vs results in the absence of tolbutamide

${ }^{\mathrm{b}} P<0.05$ vs results at $3 \mathrm{mmol} / \mathrm{l} \mathrm{D}$-glucose

${ }^{c}$ Values are means \pm SEM calculated for the indicated number of experiments

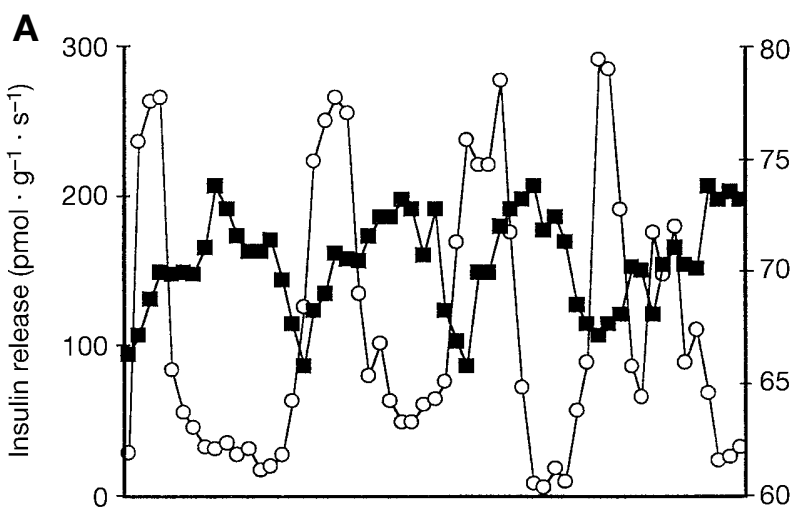

B

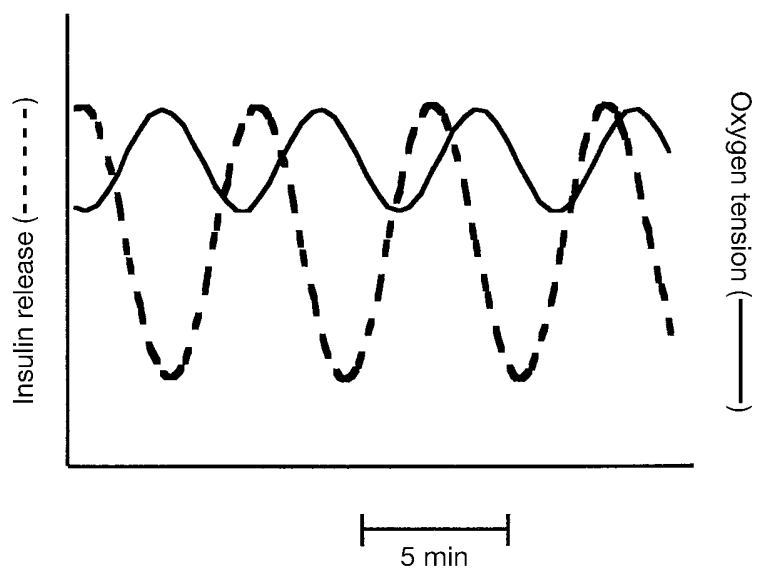

Fig. 3. A Simultaneous measurements of $\mathrm{pO}_{2}$ (closed symbols) and insulin release (open symbols) from an individual mouse islet perifused in the presence of $11 \mathrm{mmol} / \mathrm{l} \mathrm{D}$-glucose. B Corresponding sinus functions are displayed for oxygen (solid line) and insulin (broken line) measurements

addition of the non-metabolisable glucose analogue $(n=6)$.

When $1 \mathrm{mmol} / \mathrm{l}$ tolbutamide was added to the perifusion medium containing $11 \mathrm{mmol} / \mathrm{l} \mathrm{D}$-glucose no change in $\mathrm{pO}_{2}$ was observed despite a doubling of the secretory rate (Fig. 1, Table 1). Tolbutamide $(1 \mathrm{mmol} / \mathrm{l})$ was also added to islets perifused in the presence of $3 \mathrm{mmol} / \mathrm{l}$ glucose (Table 1). Although no statistically significant change in $\mathrm{pO}_{2}$ was observed, the amplitude of the insulin pulses increased sixfold.

Frequencies of oscillations in $\mathrm{pO}_{2}$ and insulin release were equal under all conditions tested (Fig.1, Table 1). Phase-shift analysis of 40 identified peaks from 14 different experiments showed, however, that peaks of oxygen and insulin oscillations did not coincide but were time-shifted $(p<0.01)$. Cross-correlation showed that peaks in $\mathrm{pO}_{2}$ preceded peaks in insulin release with $0.63 \pm 0.02$ periods. Maximum respiration (nadir in $\mathrm{pO}_{2}$ ) occurred just before maximum insulin secretion. This relation is illustrated in Figure 3 where simultaneous measurements of $\mathrm{pO}_{2}$ and insulin release in the presence of $11 \mathrm{mmol} / \mathrm{l} \mathrm{glu}-$ cose are presented.

\section{Discussion}

In our study the role of changes in $\mathrm{pO}_{2}$ for the generation of pulsatile insulin release in single islets of Langerhans was further investigated by simultaneous measurements of $\mathrm{pO}_{2}$ with a modified Clark electrode [20] and insulin release with a sensitive ELISA [1]. The combination of sensitive techniques has previously been used to evaluate the role of $\left[\mathrm{Ca}^{2+}\right]_{\mathrm{i}}$ for pulsatile insulin release from single islets $[14,16,18,19,23]$.

Attempts have previously been made to correlate oscillatory metabolism and hormonal secretion by simultaneously measuring lactate and insulin release from groups of islets [10]. Both the sampling time of $3.3 \mathrm{~min}$ and the use of approximately 200 islets in each experiment made it, however, difficult to study the correlation between these oscillations with approximately 5-min duration. Oxygen measurements of the islet had previously required groups of islets $[9,24,25,26]$ or large piscine islet organs [27]. Thus, oscillatory oxygen consumption and insulin release had to be studied in parallel using multiple islets and separate perifusion systems for the two variables [9]. Notably, periodic fluctuations of both variables could be observed. It is, however, difficult to draw any firm 
conclusions from these previous studies about the pulsatile behaviour of isolated islets because the metabolic and secretory phenomena should preferably be studied simultaneously in connected pancreatic beta cells [28]. Nevertheless, the results from these and other metabolic studies both with clonal beta cells and isolated islets $[7,8,11]$ provide evidence suggesting that an oscillating metabolism is an important factor for the generation of pulsatile insulin release [15].

Monitoring $\mathrm{pO}_{2}$ from individual islets with the aid of an oxygen microsensor $[12,13,24]$ has made it possible to observe regular fluctuations in $\mathrm{pO}_{2}$ from individual islets. In all these studies a small oxygen electrode, with a tip diameter of $2-5 \mu \mathrm{m}$ has been used. The electrode used by another group $[12,13]$ has a reference electrode placed outside the electrode as described by Davies and Brink [29]. Our electrode [22] is a Clark-type electrode with the reference electrode behind the same membrane as the sensing cathode as described by Clark [30]. The shielding electrolyte around the sensing cathode stabilises the electrode against surrounding electronic disturbances. Our electrode also has a guard-electrode behind the sensing cathode, which makes the measurements extremely stable as it eliminates any oxygen coming from behind the sensing cathode from the electrolyte reservoir. Both electrodes recorded similar values for frequency and amplitude of the pulses in oxygen tension microsensor $[12,13]$. The discrepancy between our recordings of average oxygen tension at $11 \mathrm{mmol} / \mathrm{l}$ glucose compared with those reported at $10 \mathrm{mmol} / \mathrm{l}$ of the sugar [12] is probably because of differences in islet size rather than in the electrodes as variations in islet size affect oxygen tension measurements in individual islet [12]. With our enhanced Clark-like oxygen microsensor in combination with a sensitive ELISA for insulin [1] we made simultaneous measurements of $\mathrm{pO}_{2}$ and insulin release from individual islets. Oscillations in $\mathrm{pO}_{2}$ and insulin release with the same frequency were recorded. When oscillations in oxygen tension and insulin release were cross-correlated and analysed for a temporal relation, the two variables were approximately half a cycle apart. A nadir in an oscillation of $\mathrm{pO}_{2}$, which corresponds to maximum respiration, coincided with a peak or just before a peak of an insulin pulse. The oscillatory activity of the two variables were also present at $3 \mathrm{mmol} / \mathrm{l}$ glucose or in the presence of tolbutamide when $\left[\mathrm{Ca}^{2+}\right]_{\mathrm{i}}$ is reported to be stable $[17,18,19]$. This strengthens the idea that metabolic oscillations are important for oscillatory insulin and makes metabolic oscillations a more plausible candidate for the generation of pulsatile insulin release at least when $\left[\mathrm{Ca}^{2+}\right]_{\mathrm{i}}$ is non-oscillatory.

Glucose is known to modulate the amplitude of the insulin oscillations in vivo and in vitro without affecting the oscillation frequency $[1,31,32]$. It is evi- dent from the $\mathrm{pO}_{2}$ traces in this and another study [12] that the frequency of the oxygen fluctuations did not change when the glucose concentration was altered. The amplitude of the $\mathrm{pO}_{2}$ changes did not, however, seem to change either although the corresponding measurements of insulin release showed amplitude-modulation of the insulin pulses. Rather a new level was attained from which $\mathrm{pO}_{2}$ oscillations with similar amplitude and frequency were superimposed. This could be because the islets were perifused in our study. Under quiescent conditions oscillations in oxygen tension are more pronounced [12]. Furthermore, as $\mathrm{pO}_{2}$ had to be measured in an open system with several diffusion-related variables it is difficult to judge whether the amplitudes of the $\mathrm{pO}_{2}$ fluctuations seen reflect quantitatively the actual changes in islet oxygen consumption. Alternatively, glucose-induced amplification of the amplitude of pulsatile insulin release could be related to enhancement of other triggering factors, e.g. $\left[\mathrm{Ca}^{2+}\right]_{\mathrm{i}}$ or molecules derived from glucose metabolism.

The variability observed in the glucose-induced changes in the level of oxygen tension correlated with changes in the amplitude of the insulin pulses and exemplifies the close linkage between glucose metabolism and insulin release $[24,25,33,34,35]$. The increase in the D-glucose concentration from 3 to $11 \mathrm{mmol} / \mathrm{l}$ induced a wide range in percentage decrease in $\mathrm{pO}_{2}(15-55 \%)$ with a corresponding range in insulin release $\left(40-190 \mathrm{pmol} \cdot \mathrm{g}^{-1} \cdot \mathrm{s}^{-1}\right)$ in different islets. Differences in secretorial response between islets has been shown recently[36]. Metabolic and secretory inter-islet variability could be explained by differences in the proportions of beta, alpha, delta and pp cells constituting the islet [37]. In this study we obtained, however, an equal and high amount of beta cells by using islets of similar size from the $o b /$ $o b$ mouse. These islets consist of more than $90 \%$ beta cells [22]. It is reasonable to assume that metabolic differences with correlation to secretory activity cannot only be detected in isolated beta cells [38] but also in intact islets.

The correspondence in frequencies and temporal relation between oscillations in insulin release and oxygen tension suggest a close linkage between oscillations in metabolism of the pancreatic beta cell and the generation of pulsatile insulin release.

Acknowledgements. The study was supported by grants from the Swedish Medical Research Council (12X-11203), the Swedish Diabetes Association, the Novo Nordisk Foundation, the Family Ernfors Foundation, the Gunvor and Josef Anér Foundation, the Marcus and Amalia Wallenberg Foundation and the Swedish Society for Medical Research. 


\section{References}

1. Bergsten P, Hellman B (1993) Glucose-induced amplitude regulation of pulsatile insulin secretion from individual pancreatic islets. Diabetes 42: 670-674

2. Goodner CJ, Walike BC, Koerker DJ et al. (1977) Insulin, glucagon and glucose exhibits synchronous sustained oscillations in fasting monkeys. Science 195: 177-179

3. Lang DA, Matthews DR, Peto J, Turner RC (1979) Cyclic oscillations of basal plasma glucose and insulin concentrations in human beings. N Engl J Med 301: 1023-1027

4. Lefèbvre PJ, Paolisso G, Scheen AJ, Henquin JC (1987) Pulsatility of insulin and glucagon release: physiological significance and pharmacological implications. Diabetologia 30: 443-452

5. Matthews DR, Naylor BA, Jones RG, Ward GM, Turner RC (1983) Pulsatile insulin has greater hypoglycemic effect than continuous delivery. Diabetes 32: 617-621

6. Paolisso G, Sgambato S, Torella R et al. (1988) Pulsatile insulin delivery is more efficient than continuous infusion in modulating islet cell function in normal subjects and patients with type 1 diabetes. J Clin Endocrinol Metab 66: 1220-1226

7. Corkey BE, Tornheim K, Deeney JT et al. (1988) Linked oscillations of free $\mathrm{Ca}^{2+}$ and the ATP/ADP ratio in permeabilized RINm5F insulinoma cells supplemented with a glycolyzing cell-free muscle extract. J Biol Chem 263: 4254-4258

8. Pralong WF, Bartley C, Wollheim CB (1990) Single islet beta-cell stimulation by nutrients: relationship between pyridine nucleotides, cytosolic $\mathrm{Ca}^{2+}$ and secretion. EMBO J 9: 53-60

9. Longo EA, Tornheim K, Deeney JT et al. (1991) Oscillations in cytosolic free $\mathrm{Ca}^{2+}$, oxygen consumption, and insulin secretion in glucose-stimulated rat pancreatic islets. J Biol Chem 266: 9314-9319

10. Chou HF, Berman N, Ipp E (1992) Oscillations of lactate released from islets of Langerhans: evidence for oscillatory glycolysis in beta-cells. Am J Physiol 262: E800-E805

11. Civelek VN, Deeney JT, Fusonie GE, Corkey BE, Tornheim K (1997) Oscillations in oxygen consumption by permeabilized clonal pancreatic beta-cells (HIT) incubated in an oscillatory glycolyzing muscle extract: roles of free $\mathrm{Ca}^{2+}$, substrates, and the ATP/ADP ratio. Diabetes 46: $51-56$

12. Jung S, Aspinwall C, Kennedy R (1999) Detection of multiple patterns of oscillatory oxygen consumption in single mouse islets of Langerhans. Biochem Biophys Res Commun 259: 331-335

13. Jung SK, Gorski W, Aspinwall CA, Kauri LM, Kennedy RT (1999) Oxygen microsensor and its application to single cells and mouse pancreatic islets. Anal Chem 71: 3642-3649

14. Bergsten P, Grapengiesser E, Gylfe E, Tengholm A, Hellman B (1994) Synchronous oscillations of cytoplasmic $\mathrm{Ca}^{2+}$ and insulin release in glucose-stimulated pancreatic islets. J Biol Chem 269: 8749-8753

15. Tornheim K (1997) Are metabolic oscillations responsible for normal oscillatory insulin secretion? Diabetes 46: 1375-1380

16. Gilon P, Shepherd RM, Henquin JC (1993) Oscillations of secretion driven by oscillations of cytoplasmic $\mathrm{Ca}^{2+}$ as evidenced in single pancreatic islets. J Biol Chem 268: 22265-22268

17. Westerlund J, Hellman B, Bergsten P (1996) Pulsatile insulin release from mouse islets occurs in the absence of stimulated entry of $\mathrm{Ca}^{2+}$. J Clin Invest 97: 1860-1863
18. Westerlund J, Gylfe E, Bergsten P (1997) Pulsatile insulin release from pancreatic islets with nonoscillatory elevation of cytoplasmic $\mathrm{Ca}^{2+}$. J Clin Invest 100: 2547-2551

19. Bergsten P, Lin J, Westerlund J (1998) Pulsatile insulin release: role of cytoplasmic $\mathrm{Ca}^{2+}$ oscillations. Diabetes Metab 24: $41-45$

20. Liss P, Nygren A, Revsbech NP, Ulfendahl HR (1997) Intrarenal oxygen tension measured by a modified Clark electrode at normal and low blood pressure and after injection of x-ray contrast media. Pflugers Arch 434: 705-711

21. Hellman B (1965) Studies in the obese hyperglycemic mouse. Ann NY Acad Sci 131: 541-558

22. Ortsäter H, Liss P, Lund PE, Åkerman KE, Bergsten P (1999) Dynamic measurements of oxygen tension in islets of Langerhans. Adv Exp Med Biol 471: 367-372

23. Bergsten P (1998) Glucose-induced pulsatile insulin release from single islets at stable and oscillatory cytoplasmic $\mathrm{Ca}^{2+}$. Am J Physiol 274: E796-E800

24. Hellerström C (1967) Effects of carbohydrates on oxygen consumption of isolated islets of mice. Endocrinology 81: 105-112

25. Hutton JC, Malaisse WJ (1980) Dynamics of $\mathrm{O}_{2}$ consumption in rat pancreatic islets. Diabetologia 18: 395-405

26. Conget I, Barrientos A, Manzanares JM et al. (1997) Respiratory chain activity and mitochondrial DNA content of non purified and purified pancreatic islet cells. Metabolism 46: 984-987

27. Schrezenmeier J, Gerö L, Laue C et al. (1992) The role of oxygen supply in islet transplantation. Transplant Proc 24: 2925-2929

28. Meda P, Atwater I, Goncalves A, Bangham A, Orci L, Rojas E (1984) The topography of electrical synchrony among beta-cells in the mouse islet of Langerhans. Q J Exp Physiol 69: 719-735

29. Davies PW, Brink F (1942) Microelectrodes for measuring local oxygen tension in animal tissues. Rev Sci Instrum 13: 524-532

30. Clark LC (1956) Monitor and control of blood and tissue oxygen tensions. Trans Am Soc Artif Int Org 2: 41-57

31. Matthews DR, Lang DA, Burnett MA, Turner RC (1983) Control of pulsatile insulin secretion in man. Diabetologia 24: $231-237$

32. Stagner JI, Samols E, Weir GC (1980) Sustained oscillations of insulin, glucagon and somatostatin from the isolated canine pancreas during exposure to a constant glucose concentration. J Clin Invest 65: 939-942

33. Ashcroft SJ, Weerasinghe LC, Randle PJ (1973) Interrelationship of islet metabolism, adenosine triphosphate content and insulin release. Biochem J 132: 223-231

34. Panten U, Klein $\mathrm{H}$ (1982) $\mathrm{O}_{2}$ consumption by isolated pancreatic islets, as measured in a microincubation system with a Clark-type electrode. Endocrinology 111: 1595-1600

35. Meglasson MD, Matschinsky FM (1986) Pancreatic islet glucose metabolism and regulation of insulin secretion. Diabetes Metab Rev 2: 163-214

36. Westerlund J, Lin JM, Bergsten P (1999) Secretory heterogeneity between isolated mouse islets. Diabetologia 42: 137 A (Abstract)

37. Wieczorek G, Pospischil A, Perentes E (1998) A comparative immunohistochemical study of pancreatic islets in laboratory animals (rats, dogs, minipigs, nonhuman primates). Exp Toxicol Pathol 50: 151-172

38. Pipeleers DG (1992) Heterogeneity in pancreatic beta-cell population. Diabetes 41: 777-781 